\title{
Population ecology of the sand-dwelling hermit crab Diogenes nitidimanus. IV. Larval settlement
}

\author{
Akira Asakura \\ Department of Zoology, Natural History Museum and Institute, Chiba, 955-2 Aoba-cho, Chiba-shi 280, Japan
}

\begin{abstract}
Settlement patterns of juveniles of the sand-dwelling hermit crab Diogenes nitidimanus Terao were examined in 1982 and 1983. Newly settled crabs were found from mid-August to the beginning of December, and peak settlement occurred in September. Crabs settled near the water level of extreme low water spring tide (ELWS) in the study area, where small, vacant shells were abundant. The density of settled crabs and that of small vacant shells were positively correlated in August, November and December. The recently settled crabs were not found on the upper flat (about $1 \mathrm{~m}$ above ELWS) or in the subtidal zone $5 \mathrm{~m}$ below the ELWS, in spite of the abundance of small shells at those locations. Small, vacant shells were introduced into the lower intertidal zone of the study area, and their presence may have resulted in an increase in the number of settled juveniles. This possibility suggests that shortage of small shells limits the settlement of hermit crabs.
\end{abstract}

\section{INTRODUCTION}

Settlement and metamorphosis of planktonic larvae of marine invertebrates have been reviewed extensively in recent years (Thorson 1950, 1961, 1966 , Mileikovsky 1971, 1976, Meadows \& Campbell 1972, Crisp 1974, 1976, Gray 1974, Scheltema 1976, Chia \& Rice 1978, Sastry 1983) in study which generally have been designed to increase our understanding of the spatial distribution and density of animals in nature.

In common with other decapod crustaceans, hermit crabs undergo a planktonic larval (zoea) stage, which becomes a megalopa (= glaucothöe) after several molts, settles, and metamorphoses into the benthic first crab. It is essential for the survival of hermit crabs and, therefore, for the establishment and maintenance of the crab population that glaucothöes find empty shells, because gastropod shells are an indispensable resource for hermit crabs. The shells provide protection against predators (Reese 1969, Vance 1972b) and physical stress (Reese 1969, Hazlett 1981). However, empty shells are scarce in nature (Hazlett 1970, Childress 1972, Fotheringham 1976b, Kellogg 1976, Scully 1979, Abrams 1980, 1981, Bertness 1980), and their availability may limit the size of individuals (Drapkin 1963, Markham 1968, Fotheringham 1976a, Bertness 1981a, d), the size of each clutch (Fotheringham 1980, Bertness 1981d), and the size of the population (Vance 1972a, Spight 1977).
I have studied the population ecology of and utilization of shells by the sand-dwelling hermit crab Diogenes nitidimanus on the sand flats of Amakusa, Kyushu, Japan. This species is by far the dominant species in the hermit crab assemblage of the flat, and most of the individuals use the shells of the sand snail Umbonium moniliferum, a dominant gastropod (Asakura \& Kikuchi 1984a). Ovigerous females can be found from April to November with a peak in August, and they migrate to live in the subtidal water in summer (Asakura \& Kikuchi 1984b, Asakura 1987 a, b, c, d). The duration of the egg incubation is about $2 \mathrm{wk}$ in water at 24 to $28^{\circ} \mathrm{C}$ (Asakura 1987a), and the pelagic stage lasts $20 \mathrm{~d}$ at 26 to $29^{\circ} \mathrm{C}$ (Baba \& Fukuda 1986).

This report describes the pattern of crab larval settlement in relation to the abundance of vacant gastropod shells in the substratum and to the density of the adult crab population.

\section{STUDY SITE AND METHODS}

Study site and sampling methods. A sand flat $\left(32^{\circ} 3^{\prime} \mathrm{N}, 130^{\circ} 1^{\prime} \mathrm{E}\right)$ at the northwestern corner of Amakusa Shimoshima Island, Kyushu, Japan, was selected for the study (Fig. 1; see also map in Asakura \& Kikuchi $1984 \mathrm{a})$. The flat extends about $2.5 \mathrm{~km}$ along the coast, and a strip $330 \mathrm{~m}$ wide is exposed to air at the low level of the extreme spring tide. In the subtidal zone, a 


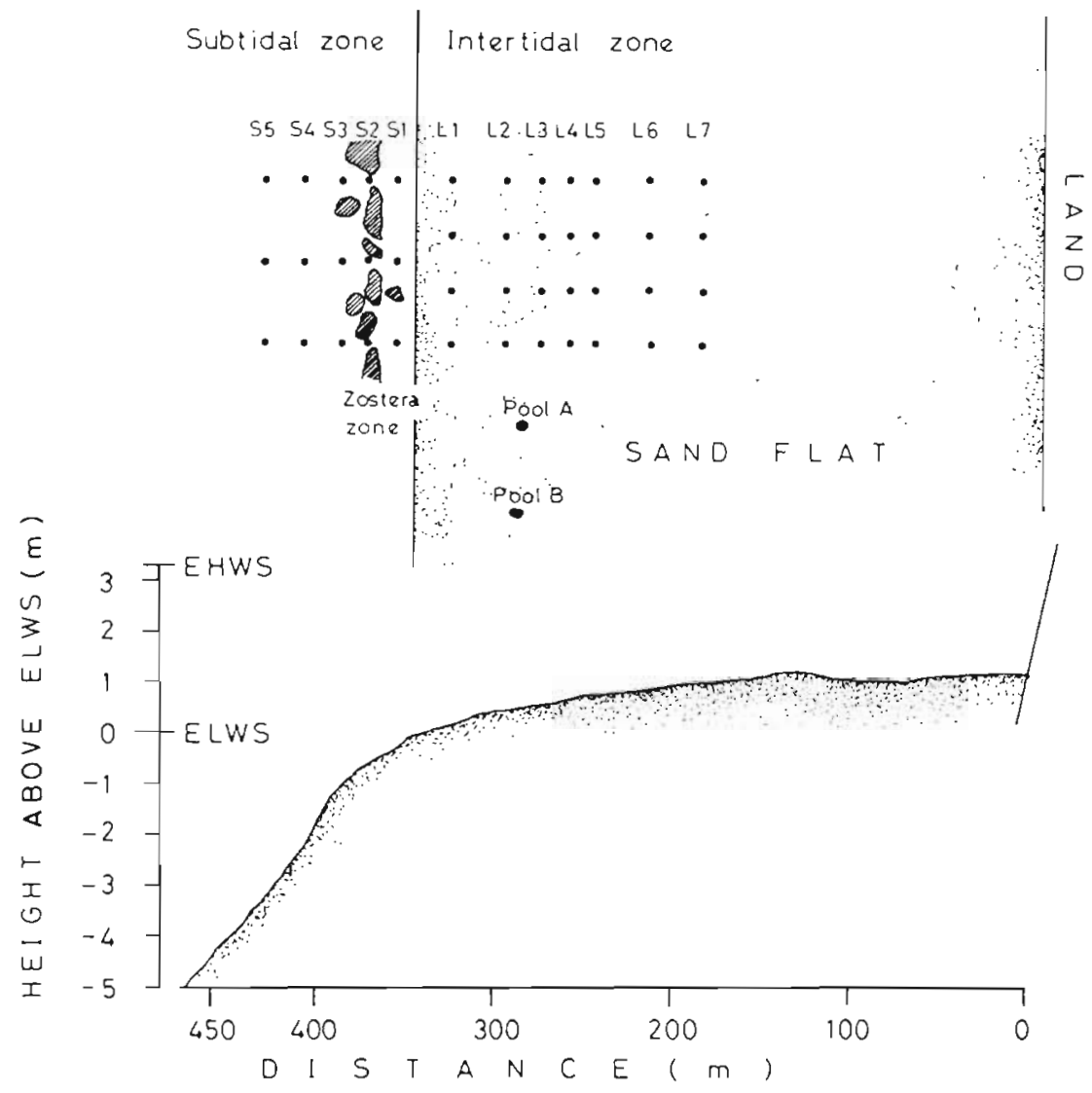

Fig. 1 Topographical profile of the sand flat and arrangement of the sampling points, with station codes. Pools A and B were used as experimental and control pools, respectively, when shells were introduced artificially. ELWS: extreme low water spring tide; EHWS: extreme high water spring tide gentle slope continues for a distance of 10 to $12 \mathrm{~m}$ into the water, and then becomes much steeper. The sediment changes from sand to sandy mud at the lower edge of the gentle slope. There are several patches of eelgrass (Zostera marina L.), submerged at a depth of less than $5 \mathrm{~m}$ at low tide (Fig. 1).

Permanent sampling points were fixed on the lower shore (28 points) and subtidal zone (15 points) of the central part of the flat (Fig. 1). I took a quadrat sample $(25 \times 25 \times 5 \mathrm{~cm})$ at each intertidal point, and a grab sample (Ekman-Birge grab sampler; $20 \times 20 \mathrm{~cm}$; mean depth $5 \mathrm{~cm}$, range 4 to $8 \mathrm{~cm}$ depending on type of sediment) at each subtidal point at the low level of spring tide, monthly, from June 1982 to June 1983.

The sampling depth $(5 \mathrm{~cm})$ was determined by the following considerations. (1) Crabs bury their bodies no more than $1.0 \mathrm{~cm}$ deep in the sand (Asakura 1984). (2) A preliminary field experiment was conducted with 3 replicates of 50 marked, small $(<5.0 \mathrm{~mm}$ in diameter), vacant shells of Umbonium moniliferum (in an area of $625 \mathrm{~cm}^{2}$ ), in the layer from 2.5 to $5.0 \mathrm{~cm}$ below the surface. After $2 w k, 16.0 \%( \pm 5.7 \%, \mathrm{SD})$ of shells had been washed out from the substratum, and, after 4 wk, an additional $22.0 \%( \pm 8.5 \%, \mathrm{SD})$ had been washed away. By way of contrast, 3 sets of marked shells in the layer from 5.0 to $7.5 \mathrm{~cm}$ below the surface were not dispersed over a period of 4 wk (Asakura 1984). Based on these results, although shells buried at a depth of more than $2 \mathrm{~cm}$ were obviously too deep for crabs to use immediately, such shells were considered to be potentially available for crabs during the considerable time span of this experiment.

The sediment samples were sieved through $0.5 \mathrm{~mm}$ mesh, and hermit crabs, gastropods, and vacant shells were sorted from the residue in the sieve, fixed in a $10 \%$ formalin solution, and identified to species. The shield length (SL, hard portion of the carapace; McLaughlin 1980) of each $\mathrm{crab}$ and the diameter of each shell were measured with an ocular micrometer.

Crabs less than $1.0 \mathrm{~mm}$ in SL were regarded as recently settled and are defined here as juveniles, because just-settled crabs ( $\mathrm{SL}=0.5 \pm 0.05 \mathrm{~mm}$ ) grew to $1.0 \mathrm{~mm}$ in SL within $7 \mathrm{~d}$ during culture in the laboratory with sufficient food and a supply of shells (Asakura 1987a).

Factors influencing distribution of juveniles. The relationship between the distribution of juveniles and that of crabs more than $1.0 \mathrm{~mm}$ in SL was examined and assessed in terms of the correlation coefficient, $r$.

To investigate the spatial distribution of small shells acceptable to the recently settled crabs, the sizes of such shells were assessed by measuring shells already 
Table 1. Diogenes nitidimanus. Sizes of shells utilized by newly settled hermit crabs $(<1.0 \mathrm{~mm} \mathrm{SL})$. Shells were collected from the sampling points in the study area shown in Fig. $1 ; 377$ juveniles were examined

\begin{tabular}{|lcr|}
\hline Species & $\begin{array}{c}\text { Shell diameter } \\
(\mathrm{mm})\end{array}$ & $\begin{array}{c}\text { No. of crabs } \\
\text { examined }\end{array}$ \\
\hline Cantharidus japonicus & $1.80-4.50$ & 23 \\
Iwakawatrochus eucosmius & $2.50-4.65$ & 6 \\
Umbonium moniliferum & $1.90-4.80$ & 140 \\
Batillaria multiformis & $1.35-4.00$ & 25 \\
Australaba picta & $1.30-4.00$ & 28 \\
Proclava kochi & $1.60-3.90$ & 7 \\
Bedevina birileffi & $2.20-3.35$ & 27 \\
Mitrella lischkei & $1.30-3.35$ & 16 \\
Reticunassa japonica & $1.35-3.25$ & 40 \\
Hinia festiva & $1.70-3.80$ & 19 \\
Niotha livescens & $1.50-3.55$ & 8 \\
Nassariidae g. sp. & $1.70-3.20$ & 15 \\
Paradrillia consimilis & $1.80-3.25$ & 8 \\
Terebridae g. sp. & $2.05-3.20$ & 15 \\
\hline
\end{tabular}

occupied by 377 crabs of less than $1.0 \mathrm{~mm}$ SL. They were collected from the study area shown in Fig. 1 during the period from June 1982 to June 1983. Table 1 shows the sizes of these shells, which are defined here, as 'suitable' for recently settled crabs.

The relationship between the distribution of juveniles and that of the small vacant shells was examined and assessed in terms of the correlation coefficient, $r$, for all sampling stations (rows of sampling points) and for all stations excluding peripheral ones (L6, L7 and S5; see Fig. 1), where both adults and juveniles were very rare (see 'Results').

Introduction of small shells. To examine the influence of a high density of small vacant shells on crab settlement, a large number of small shells acceptable to juveniles was introduced onto the flat.

In March 1984, a considerable quantity (ca $120 \mathrm{~m}^{3}$ ) of dredged sediment, including pebbles, was dumped onto the lower part of the sand flat, forming a mound about $18 \mathrm{~m}$ in diameter and $75 \mathrm{~cm}$ in height at its thickest point. Two shallow pools, situated $15 \mathrm{~m}$ from each other, formed naturally, landward of the mound (Pools A and B in Fig. 1), as a result of alterations in the discharge route of seawater at low tide.

About 10000 vacant shells of young Batillaria multiformis ( $<4.0 \mathrm{~mm}$ in diameter, suitable size for use by juveniles; see Table 1) were introduced on 2 August 1984 into Pool A $\left(72 \mathrm{~m}^{2}\right)$. [Ovigerous females are present at the highest density during August (Asakura \& Kikuchi 1984b).] The vacant shells were those of snails which had been collected at a separate site and boiled and cleaned to remove the flesh. Pool $B\left(80 \mathrm{~m}^{2}\right)$ remained in its natural state, as a control. The environmental conditions of both pools were very similar, i.e. they were situated at the same tidal level, mean water depths at low tide were ca $10 \mathrm{~cm}$, bottoms were very smooth, and the bottom sediment was sand. At low water of spring tide (the period from 8 to 12 August and from 24 to 30 August), juvenile crabs were collected by sieving sediment from the upper $1 \mathrm{~cm}$ layer at the bottom of the pools through $0.5 \mathrm{~mm}$ mesh. Juveniles bury their bodies within $0.5 \mathrm{~mm}$ of the surface at the time of low water (Asakura unpubl.), so the sampling depth was adequate for such collection.

The sampling was completed on 30 August (1 mo after shell introduction) for the following reason. In a preliminary field experiment, in which 3 replicates of 50 marked, small $(<5.0 \mathrm{~mm}$ in diameter), vacant shells (in an area of $625 \mathrm{~cm}^{2}$ ) were placed on the surface of the sand flat, the shells disappeared from the surface within $3 \mathrm{~d}$, some being lost by wave action, others being buried in the sand. After $2 \mathrm{wk}$, no shells remained in the upper $2.5 \mathrm{~cm}$ layer, and $74.0 \%( \pm 2.8 \%, \mathrm{SD})$ of the marked shells were found at a depth of more than $2.5 \mathrm{~cm}$ (Asakura 1984). Thus, 1 mo was considered sufficient time to allow for most of the introduced shells to be buried deeper than $2.5 \mathrm{~cm}$ depth or to be washed away, with no available introduced shells remaining in the upper $2.5 \mathrm{~cm}$ layer

\section{RESULTS}

Seasonal variations in the numbers of juveniles collected are shown in Fig. 2. Juveniles appeared from 19 August to 1 December 1982. No juveniles were collected on 3 and 21 July 1982 or during the sampling period from 16 December 1982 to 11 June 1983.

Fig. 3 shows the spatial distribution pattern of the juveniles. The higher densities of juveniles were observed near the water level of ELWS (extreme low water spring tide), i.e. at the sampling points on the lower half of the flat in August (L1), September (L1), October (L2) and November (L2), and at the sampling points in the upper subtidal zone in December (S2). Thus, the main settlement area was between Stns S3 and L4. The juveniles seldom settled in the upper flat (above Stn L4) or in the lower subtidal zone (below Stn S3).

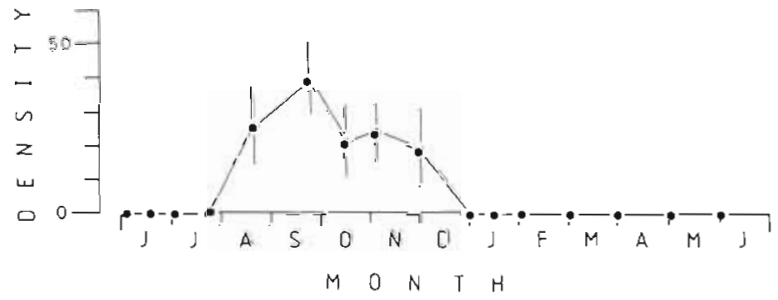

Fig. 2. Diogenes nitidimanus. Seasonal changes in the density (no. per $7500 \mathrm{~cm}^{2}$; means $\pm \mathrm{SD}$ ) of newly settled juveniles $(<1.0 \mathrm{~mm} \mathrm{SL})$ in the study area, 1982 and 1983 

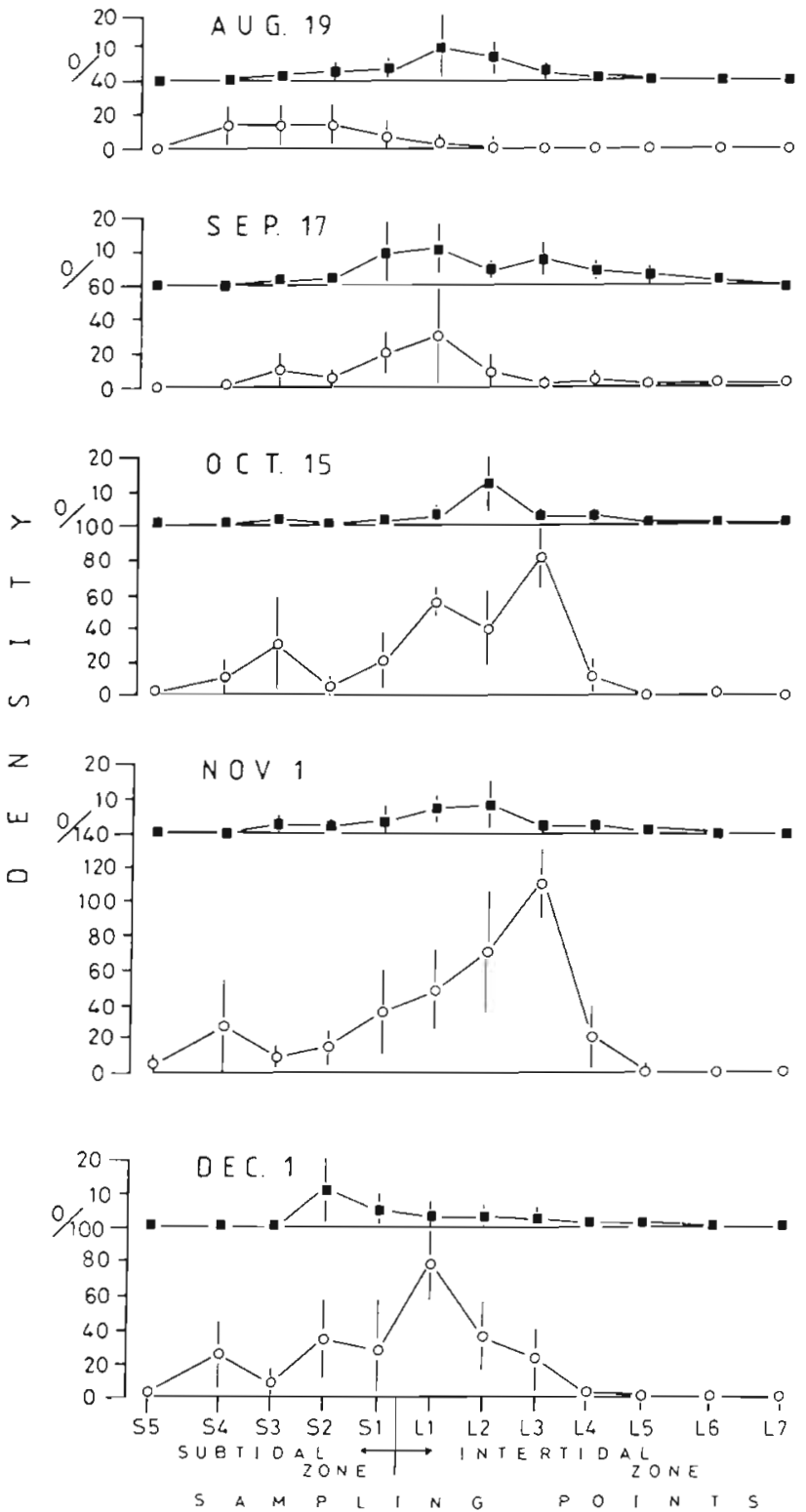

Fig. 3. Diogenes nitidimanus. Changes in distribution patterns of newly settled juveniles $(<1.0 \mathrm{~mm} \mathrm{SL}--)$ and larger crabs ( $\geq 1.0 \mathrm{~mm} \mathrm{SL}$ - from August to December 1982 Density: no. per $625 \mathrm{~cm}^{2}$; means $\pm S D$. No juveniles were collected in June and July 1982 or from January to June 1983 (see Fig. 2)

Significant positive correlations were detected between the distribution of the juveniles and that of crabs larger than $1.0 \mathrm{~mm}$ SL for the period from September to December (Table 2).

The temporal patterns of distribution of vacant shells sujtable for the settled juveniles (see Table 1) are shown in Fig. 4. Three obvious regions of increased density of shells were observed in most months: around the stations on the upper flat (L6 and L7), near the ELWS stations (L1 and L2), and around the lower subtidal stations (S5).
82 JULY 21

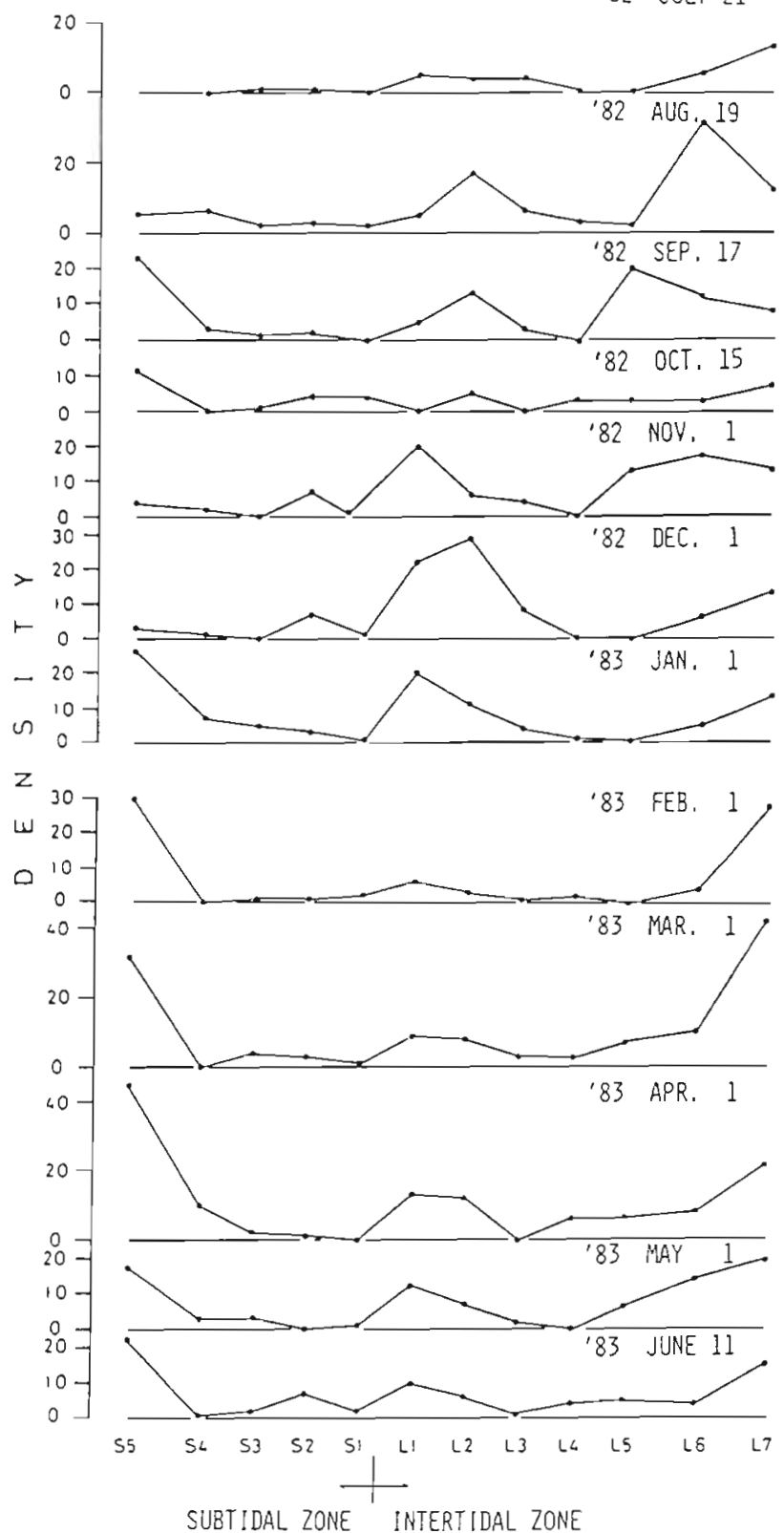

SAMPLING POINTS

Fig. 4. Distribution pattern of the small vacant shells suitable for newly settled hermit crabs Diogenes nitidimanus $<1 \mathrm{~mm}$ SL) along the sampling transects in 1982 and 1983. Density: no. per $625 \mathrm{~cm}^{2}$

Each region corresponds to the presence of different kinds of shell. The upper intertidal zone is inhabited by small individuals of Umbonium moniliferum $<5.0 \mathrm{~mm}$ in diameter), which migrate into the lower intertidal zone as they grow and die, in particular from March to May (Tamaki 1984a, Asakura 1987a). The large number of shells of Cantharidus japonicus in the subtidal zone was derived from the patches of Zostera marina (Asakura \& Kikuchi 1984a). The shells collected 
Table 2. Diogenes nitidimanus. Correlation between the density of newly settled crabs ( $<1.0 \mathrm{~mm} \mathrm{SL}$ ) and that of crabs $>1.0 \mathrm{~mm}$ SL (sample size $=43$ for each month and 215 for all data from $5 \mathrm{mo}$ ). r: correlation coefficient

\begin{tabular}{|lc|}
\hline Date (1982) & $\mathrm{r}$ \\
\hline $19 \mathrm{Aug}$ & -0.17 \\
17 Sep & $0.57^{\cdots}$ \\
15 Oct & $0.35^{\circ}$ \\
1 Nov & $0.47^{\cdots}$ \\
1 Dec & $0.63^{\cdots}$ \\
All 5 months & $0.27 \cdots$ \\
$p<0.05, \cdots p<0.01, \cdots p<0.005$ & \\
\hline
\end{tabular}

near ELWS were of many different types, coming from both the intertidal and subtidal areas and from both soft and hard bottoms (Asakura \& Kikuchi 1984a).

In the main settlement area (Stns S4 to L5), positive correlations were detected between the distribution of the juveniles and that of the small shells during the entire period from August to December; these correlations were significant in August, November and December (Table 3). In contrast, in the entire sampling area, no significant correlation was detected in August, October, November and December, and even a negative correlation was found in September.

The introduction of small shells (Pool A) resulted in an increase in the number of juveniles, as compared with the control area (Table 4). No small vacant shells remained in the upper $1 \mathrm{~cm}$ layer of bottom sand in the control pool at the end of the observation. At no time during the study period did juveniles under natural conditions attain the high densities found in Pool A.

\section{DISCUSSION}

\section{Factors influencing spatial distribution of juveniles}

There was a general tendency for juveniles to appear near the water level of ELWS, between Stns L5 and S4. Adult crabs also predominantly inhabited this area, and a positive correlation between the distribution of juveniles and that of adults was seen from September to December. However, no such correlation was seen in August, so the seasonal migration of adults (Asakura \& Kikuchi 1984a) seems to have no major effect on the distribution of juveniles. However, since the influence of adults on larval settlement has frequently been reported for many marine invertebrates (Allen 1963, Crisp 1964, 1974, 1976, Thorson 1966, Woodin 1974 , Brock 1980, Peterson 1982), further detailed investigation of this issue is necessary.
Table 3. Diogenes nitidimanus. Correlation between the density of newly settled crabs ( $<1.0 \mathrm{~mm} \mathrm{SL}$ ) and that of small vacant shells (see Table 1). Sampling Group 1. calculations for all of the sampling stations (sample size $=43$ for each month and 215 for all data from 5 mo); Sampling Group 2: calculations for all of the stations except for those on the periphery of the study area (L6, L7, and S5) (sample size $=32$ for each month and 160 for all data from $5 \mathrm{mo}$ ). r: correlation coefficient

\begin{tabular}{|c|c|c|}
\hline Date (1982) & $\begin{array}{l}\text { Sampling } \\
\text { group }\end{array}$ & r \\
\hline $19 \mathrm{Aug}$ & $\begin{array}{l}1 \\
2\end{array}$ & $\begin{array}{l}0.16 \\
0.81 \cdots\end{array}$ \\
\hline $17 \mathrm{Sep}$ & $\begin{array}{l}1 \\
2\end{array}$ & $\begin{array}{c}-0.43^{\cdots} \\
0.20\end{array}$ \\
\hline $15 \mathrm{Oct}$ & $\begin{array}{l}1 \\
2\end{array}$ & $\begin{array}{r}-0.20 \\
0.09\end{array}$ \\
\hline $1 \mathrm{Nov}$ & $\begin{array}{l}1 \\
2\end{array}$ & $\begin{array}{r}-0.21 \\
0.35\end{array}$ \\
\hline $1 \mathrm{Dec}$ & $\begin{array}{l}1 \\
2\end{array}$ & $\begin{array}{r}-0.04 \\
0.35\end{array}$ \\
\hline All 5 months & $\begin{array}{l}1 \\
2\end{array}$ & $\begin{array}{r}-0.08 \\
0.25\end{array}$ \\
\hline
\end{tabular}

The area near ELWS also contained many shells, and there was a significant positive correlation between the distribution of the juveniles and that of the small shells in most months. In some cases, values of the correlations were rather low or not significant. This is probably because I collected crabs within $1 \mathrm{wk}$ after settlement (see 'Methods'), so that they had time to become slightly dispersed from the settlement points.

Table 4. Diogenes nitidimanus. Numbers of newly settled crabs ( $<1.0 \mathrm{~mm} \mathrm{SL}$ ) in pool $\mathrm{A}$, into which ca 10000 vacant small shells of Batillaria multiformis were introduced on 2 August and in the control pool (Pool B)

\begin{tabular}{|lrc|}
\hline Date (1984) & \multicolumn{2}{c|}{ No. of juveniles } \\
& Pool A & Pool B \\
\hline 8 Aug & 80 & 6 \\
9 Aug & 76 & 7 \\
10 Aug & 15 & 3 \\
11 Aug & 0 & 0 \\
12 Aug & 2 & 0 \\
24 Aug & 45 & 1 \\
25 Aug & 104 & 3 \\
26 Aug & 44 & 2 \\
27 Aug & 7 & 0 \\
28 Aug & 0 & 0 \\
29 Aug & 32 & 2 \\
30 Aug & 21 & 0 \\
Total & 426 & 24 \\
\hline
\end{tabular}


Although there appeared to be more shells available in this area, those which were immediately available for juveniles were completely utilized, probably for the following reason. The vertical distribution of vacant shells in the sand on the flat was studied previously by analysis of core samples (cross-sectional area = $100 \mathrm{~cm}^{2} ; 5 \mathrm{~cm}$ depth) taken from each sampling point (Asakura 1984). The small shells in the upper $1 \mathrm{~cm}$ layer accounted for only $11.42 \%$ ( $\pm 10.06 \%, \mathrm{SD} ; \mathrm{n}=$ $55)$ of the total number of shells in the upper $5 \mathrm{~cm}$ layer. The rest were buried at depths greater than $2 \mathrm{~cm}$, so that crabs could not immediately utilize them, although they were potentially available over the long term (as mentioned in the 'Methods'). Thus, most of the shells in the area near ELWS were believed to be buried at a depth of more than $2 \mathrm{~cm}$.

In the lower subtidal zone, juveniles were scarce despite the abundance of shells. Since very few adults were found there (Fig. 3), the depth of seawater (ca $5 \mathrm{~m}$ at low tide) may limit the distribution of crabs. This species generally inhabits intertidal and very shallow subtidal areas less than $3 \mathrm{~m}$ in depth, and their seasonal migration occurs in these areas (Miyake \& Imafuku 1980, Nojima et al. 1980, Asakura \& Kikuchi 1984a, b, Asakura 1987a).

Juveniles were also scarce in the upper flat in spite of the abundance of small shells. This scarcity was probably due to the presence of ghost shrimp Callianassa japonica. The fauna of this same flat has been intensively investigated by Tamaki (Tamaki \& Kikuchi 1983. Tamaki 1984a, b, 1985a, b, c, 1986, 1987, 1988), who found that $C$. japonica had recently invaded the upper flat, attained a high density (mean 330 ind. $\mathrm{cm}^{-2}$ in 1982, above Stn L5), and inhibited the habitation and settlement of many animals, including Diogenes nitidimanus (Tamaki 1984a). Such negative effects of ghost shrimp on other organisms have also been reported by others recently (Aller \& Dodge 1974, Peterson 1977, Posey 1986, Suchanek \& Colin 1986, Suchanek et al. 1986).

However, if we are to define completely those factors that limit the upper distribution of juveniles, we must also investigate other possibilities, such as physical effects that influence conditions on the upper flat (desiccation, extreme temperature upon emersion, etc.) and may affect settlement.

\section{Population process and small-shell limitation}

The results of the shell introduction experiment suggest that high numbers of small shells may increase the number of settled crabs on the flat. In general, there is much inferential and little direct evidence to indicate that the number of shells limits the population size of hermit crabs (Vance 1972a, Spight 1977, Wilber \& Herrinkind 1984; see Hazlett 1981 for review). Earlier studies have not, however, included any emphasis on the size of shells.

Nevertheless, the presence of many small shells in the field has been observed by Vance (1972a), Fotheringham (1976b), Conover (1979), and Hazlett (1981). It has also been reported that small crabs have used shells of a preferred size in several populations (Vance 1972a, Bertness 1980, 1981b, c). Fotheringham (1976b) and Hazlett (1981) concluded that, in the field, there is a surplus of appropriate-sized shells for recently settled crabs. The results of the present study are not in agreement with their conclusion; this discrepancy may arise from a failure to consider the population processes of both hermit crabs and gastropods.

The stages at which shells are scarce should be related to the size of crabs, particularly the size during settlement by larvae and during the growth period, and when the crabs are mature adults. In temperate regions, these stages cycle seasonally, because reproduction of most species of hermit crabs is seasonal (see discussion in Asakura \& Kikuchi 1984b). Temperate gastropods also exhibit seasonality in their growth and survival (Underwood 1979). Therefore, an appropriate determination of whether shells are scarce or abundant is complex, since relative scarcity or abundance depends on timing and on the balance between the number and size of shells produced by snail populations and the number and size of shells required by hermit crab populations.

Acknowledgements. The author expresses his sincere gratitude to Prof. T Kikuchi of the Amakusa Marine Biological Laboratory of Kyushu University for his encouragement during the course of this study. Cordial thanks are also given to Drs M. Tanaka, S. Nojima, and A. Tamaki for their valuable suggestions and encouragement during the investigation Thanks also to Mr R. K. Nakamura for helpful comments on the manuscript and to Dr A. M. Körner for improving the English

\section{LITERATURE CITED}

Abrams, P. A. (1980). Resource partitioning and interspecific competition in a tropical hermit crab community. Oecologia 46: 365-379

Abrams, P. A. (1981). Competition in an Indo-Pacific hermit crab community. Oecologia 51: 240-249

Allen, J. A. (1963). Observations on the biology of Pandals montagui (Crustacea: Decapoda). J. mar biol. Ass. U.K. 43: $665-682$

Aller, R. C . Dodge, R. E. (1974). Anımal-sediment relations in a tropical lagoon, Discovery Bay, Jamaica. J. mar. Res. 32: 209-232

Asakura, A. (1984). Dynamics of the shell utılization system of the hermit crab, Diogenes nitidimanus Terao. M.Sc. thesis, Kyushu University, Fukuoka 
Asakura, A. (1987a). Dynamic aspects of the population and shell utilization of the sand dwelling hermit crab, Diogenes nitidimanus Terao. Ph.D. thesis, Kyushu University, Fukuoka

Asakura, A. (1987b). Population ecology of the sand-dwelling hermit crab. Diogenes nitidimanus Terao. 3. Mating system. Bull. mar. Sci. 41. 226-233

Asakura, A. (1987c). Polymorphism in chelae of Diogenes nitidimanus Terao (Decapoda. Anomura: Diogenidae) Res. Crust. 16: 29-33

Asakura, A. (1987d). Preliminary observations on the offshore mass migration of the sand-dwelling hermit crab, Diogenes nitidimanus Terao. J. Ethol. 5: 207-209

Asakura, A., Kikuchi, T. (1984a). Population ecology of the sand dwelling hermit crab, Diogenes nitidimanus Terao. 1. Shell utilization. Publs Amakusa mar biol. Lab. 7: 95-108

Asakura, A., Kikuchi, T. (1984b). Population ecology of the sand dwelling hermit crab, Diogenes nitidimanus Terao. 2 Migration and life history. Publs Amakusa mar. biol. Lab. 7: $109-124$

Baba K., Fukuda, Y (1986). Larval development of the hermit crab Diogenes nitidimanus Terao, 1913 (Crustacea: Anomura: Diogenidae) reared in the laboratory. Mem. Fac Educ. Kumamoto Univ. Nat. Sci. 34: 5-17

Bertness, M. D. (1980). Shell preference and utilization patterns in littoral hermit crabs of the bay of Panama. J. exp. mar. Biol. Ecol. 48: 1-16

Bertness, M. D. (1981a). Influence of shell-type on hermit crab growth rate and clutch size (Decapoda, Anomura). Crustaceana 40: 197-205

Bertness, M. D. (1981b). Interference, exploitation and sexual components of competition in a tropical hermit crab assemblage. J. exp. mar. Biol. Ecol. 49: 189-202

Bertness, M. D. (1981c). Competitive dynamics of a tropical hermit crab assemblage. Ecology 62: 751-761

Bertness, M. D. (1981d). Pattern and plasticity in tropical hermit crab growth and reproduction. Am. Nat. 117: 754-773

Brock, V. (1980). Notes on relations between density, settling, and growth of two sympatric cockles, Cardium edule (L.) and C. glaucum (Bruguire). Ophelia (Suppl.) 1 241-248

Chia, F. S., Rice, M. E. (eds.) (1978). Settlement and metamorphosis of marine invertebrate larvae. Elsevier, New York

Childress, J. R. (1972). Behavioral ecology and fitness theory in a tropical hermit crab community. Ecology 53: 960-964

Conover, M. R. (1979). Effect of gastropod shell characteristics and hermit crabs on shell epifauna. J. exp. mar. Biol. Ecol. 40: 81-94

Crisp. D. J. (1964). Assessment of plankton grazing by barnacles. In: Crisp, D. J. (ed.) Grazing interrestrial and marine environment. Blackwell Scientific Publications, Oxford, p. $251-264$

Crisp, D. J. (1974). Factors influencing the settlement of marine invertebrate larvae. In: Grant, P. T., Mackie, A. N. (eds.) Chemoreception in marine organisms. Academic Press, New York, p. 177-265

Crisp, D. J. (1976). Settlement responses in marine organisms. In: Newell, R. C. (ed.) Adaptations to environment: essays on the physiology of marine animals. Butterworths, London. p. 83-124

Drapkin, E. I. (1963). Effect of Rapana bezear Linne (Mollusca, Muricidae) on the Black Sea fauna. Dokl. Akad. Nauk SSSR 151: 700-703 (English transl.; Biol. Sci. Sect. 151: 964-966, 1964)

Fotheringham, N. (1976a). Population consequence of shel utilization by hermit crabs. Ecology 57:570-578

Fotheringham, N. (1976b). Hermit crab shells as a limiting resource (Decapoda, Paguridea). Crustaceana 31: 193-199
Fotheringham, N. (1980). Effects of shell utilization on reproductive pattern in tropical hermit crabs. Mar. Biol. 55 $287-293$

Gray, J. S. (1974). Animal-sediment relationships. Oceanogr mar. Biol. Ann. Rev. 12: 223-261

Hazlett, B. A. (1970). Interspecific shell fighting in three sympatric species of hermit crabs in Hawaii. Pacif. Sci. 24 $472-482$

Hazlett, B. A. (1981). Behavioral ecology of hermit crabs. Ann Rev. Ecol. Syst. 12: 1-22

Kellogg, C. W. (1976). Gastropod shells: potentially limiting resource for hermit crabs. J. exp. mar. Biol. Ecol. 22 101-111

Markham, J. C. (1968). Notes on growth patterns and shell utilizations of hermit crab Pagurus bernhardus. Ophelia 5 189-205

McLaughlin, P. A. (1980). Comparative morphology of recent Crustacea. W. H. Freeman \& Co., San Francisco

Meadows, P. S., Campbell, J. I. (1972). Habitat selection by aquatic invertebrates. Adv. mar Biol. 10: 271-382

Mileikovsky, S. A. (1971). Types of larval development in marine bottom invertebrates, their distribution and ecological significance. Mar Biol. 10: 193-213

Mileikovsky, S. A. (1976). Types of marine bottom invertebrates: an integrated ecological scheme. Thalassia jugosl. 10: $171-179$

Miyake, S., Imafuku, M. (1980). Hermit crabs from the Kil Peninsula. Nanki Seibutu 22: 1-7

Nojima, S., Kitajima, Y., Kuwahara, Y., Miyamoto, S., Furunishi, S. (1980). Preliminary report on a food web in a tidal sand flat, with special reference to a subweb centering around a sand snail, Umbonium (Suchium) moniliferum. J. Jpn. Ass. Benthol. 19/20: 71-80

Peterson, C. H. (1977). Competitive organization of the softbottom macrobenthic communities of southern California lagoons. Mar. Biol. 43: 343-359

Peterson, C. H. (1982). The importance of predation and intraand interspecific competition in the population biology of two infaunal suspension-feeding bivalves, Protothaca staminea and Chione undatella. Ecol. Monogr. 53: $437-475$

Posey, M. H. (1986). Changes in a benthic community associated with dense beds of a burrowing deposit feeder, Callianassa californiensis. Mar Ecol. Prog. Ser. 31: 15-22

Reese, E. S. (1969). Behavioral adaptation of intertidal hermit crabs. Am. Zool. 9: 343-355

Sastry, A. N. (1983). Pelagic larval ecology and development. In: Vernberg, F. J., Vernberg, W B. (eds.) The biology of Crustacea, Vol 7. Behavior and ecology. Academic Press, New York, p. 213-282

Scheltema, R. S. (1976). Biological interactions determining larval settlement of marine invertebrates. Thalassia jugosl. 10: $263-296$

Scully, E. P. (1979). The effects of gastropod shell availability and habitat characteristics on shell utilization by the intertidal hermit crab, Pagurus longicarpus Say. J. exp. mar Biol. Ecol. 37: 139-152

Spight, T. M. (1977). Availability and use of shells by intertidal hermit crabs. Biol. Bull, mar biol. Lab., Woods Hole 152: $120-133$

Suchanek, T. H. Colin, P. L. (1986). Rates and effects of bioturbation by invertebrates and fishes at Enewetak and Bikini Atolls. Bull. mar. Sci. 38: 25-29

Suchanek, T H., Colin, P. L., McMurtry, G. M., Suchanek, C. S. (1986). Bioturbation and redistribution of sediment radionuclides in Enewetak Atoll lagoon by callianassid shrimp: biological aspects. Bull. mar Sci. 38: 144-154 
Tamaki, A. (1984a). Study on dynamics of the benthic community on an intertidal sand flat, with special reference to biological interactions in the same trophic level. Ph.D. thesis, Kyushu Univ., Fukuoka

Tamaki, A. (1984b). Structural characteristics of an intertidal sand flat in Tomioka Bay, Amakusa, west Kyushu. Publs Amakusa mar biol. Lab. 7: 125-150

Tamaki, A. (1985a). Inhibition of larval recruitment of Armandia sp. (Polychaeta, Opheliidae) by established adults of Pseudopolydora paucibranchiata (Okuda) (Polychaeta, Spionidael on an intertidal sand flat. J. exp. mar. Biol. Ecol. $87 \cdot 67-82$

Tamaki, A. (1985b). Detection of non-interference within a mobile polychaete species. J. exp. mar. Biol. Ecol. 90: 277-287

Tamaki, A. (1985c). Zonation by size in the Armandia sp. (Polychaeta: Opheliidae) population on an intertidal sand flat. Mar. Ecol. Prog. Ser 27: 123-133

Tamaki, A. (1986). Current studies on species interactions and community ecology of macrobenthos in intertidal flat: a review. Jpn J. Ecol. 36: 55-68

Tamaki, A. (1987). Comparison of resistivity to transport by wave action in several polychaete species on an intertidal sand flat. Mar. Ecol. Prog. Ser 37: 181-189

Tamaki, A. (1988). Effects of the bioturbating activity of the ghost shrimp Callianassa japonica Ortmann on migration of a mobile polychaete. J. exp. mar. Biol. Ecol. 120: 81-95

This article was submitted to the editor
Tamaki, A. Kikuchi, T. (1983). Spatial arrangement of macrobenthic assemblages on an intertidal sand flat, Tomioka Bay, west Kyushu. Publs Amakusa mar biol. Lab. 7 $41-60$

Thorson, G. (1950). Reproductive and larval ecology of marine bottom invertebrates. Biol. Rev. 25: 1-45

Thorson, G. (1961). Length of pelagic life in marine bottom invertebrates as related to larval transport by ocean current. In: Sears, M. (ed.) Oceanography. Am. Ass. Adv. Sci. Publ. 67, Washington, D.C., p. 455-474

Thorson, G. (1966). Some factors influence the recruitment and establishment of marine benthic communities. Neth. J. Sea Res. 3: 267-293

Underwood, A. J. (1979). The ecology of intertidal gastropods. Adv. mar. Biol. 16: 111-210

Vance, R. R. (1972a). Competition and mechanism of coexistence in three sympatric species of intertidal hermit crabs. Ecology 53: 1062-1074

Vance, R. R. (1972b). The role of shell adequacy in behavioral interactions involving hermit crabs. Ecology 53: 1075-1083

Wilber, T. P., Herrinkind, W. F. (1984). Predaceous gastropods regulate new-shell supply to salt marsh hermit crabs. Mar. Biol. 79: 145-158

Woodin, S. A. (1974). Polychaete abundance pattern in a marine soft-sediment environment: the importance of biological interactions. Ecol. Monogr. 44: 171-187

Manuscript first received: January 29, 1988

Revised version accepted: October 10, 1991 